\title{
INFLUENCE OF THE COMBINE HARVESTER PARAMETER SETTINGS ON HARVEST LOSSES
}

\author{
Martin ŠOTNAR*, Jiří POSPÍŠIL, Jan MAREČEK, Tereza DOKUKILOVÁ, Vojtěch NOVOTNÝ \\ Mendel University in Brno, Czech Republic
}

\begin{abstract}
This paper deals with the relationship between grain yield and grain losses during harvest. Measurements were carried out on a combine harvester with axial harvesting device allowing various adjustments to combine harvester parameter settings, such as rotor speed, gap between separator and rotor, fan speed, holes of the upper and lower sieves. Values of harvest losses in combine harvester with custom settings for the given crops were compared with values of losses obtained by a harvester with manufacturer's recommended settings. This paper observes the losses in grains of spring barley and winter wheat crops. All the measurements made showed lower grain losses when the combine harvester settings were customized. In general, custom settings provided quantitative losses lower by $0.198 \%$ than settings recommended by manufacturer.
\end{abstract}

Keywords: harvest losses; combine harvester parameters; biological grain yield; spring barley; winter wheat

For sustainable agriculture, the main challenge is to satisfy the growing demand for food as a result of the growing population, global climate changes (Kahil et al., 2015) and overall water resources management based on its consumption and environmental utilization (Elliot et al., 2014). The world's most cultivated crops are cereals (maize, rice, wheat and barley). Barley (Hordeum vulgare L.) is widespread throughout the entire world and interest in its use is currently increasing due to its importance for human nutrition (Lahouar et al., 2012), mainly due to the high content of vitamin E, beta-glucan and fibre (Do et al., 2015). Another advantage of barley in comparison to wheat lies in its ability to provide high yields even when grown under stressful conditions such as relative drought (Wahbi and Sinclair, 2005), higher salinity or generally poor soil quality (Kaniewski et al., 2012).

Modern and efficient use of all available options is a necessary prerequisite for increasing productivity in agriculture, in which the number of workers is decreasing. For example, the number of agricultural workers decreased by $25 \%$ between 2000 and 2009 in the European Union (EU27) (Eurostat, 2010). Therefore, improving efficiency is one of the most important tasks for agricultural mechanization (Kutzbach, 2000). This is especially true for the efficiency of transport activities, which are characterized by high intensity in agriculture (Dimitrov et al., 2012).

By adjustment and modification of the combine harvester basic parameters, the efficiency of machine can be increased, resulting in reduction of operating costs. For example, automatic guidance systems for combine harvester increase its seasonal performance, precision and safety (Coen et al., 2008). Furthermore, these systems reduce operator workload and operator is able to concentrate more on harvesting process (Gerrish et al., 1997).
The parameter of harvest losses represents one of the determining efficient harvest parameters. Not only do these losses reduce the profits of farmers but also partially nullify the breeders' efforts to get rid of the grain to disperse seeds (Ibanez et al., 2014). Consequently, harvest losses play a role in other environmental processes, such as the problem of nitrogen loss from soil system (Jones and Dalal, 2017). Harvest losses also facilitate the spread of unwanted pests, such as insects, which are considered one of the largest cereal pests (Alonso-Amelot and Avila-Núñez, 2011). For example, in dry soils in northern Spain, the harvester ant Messor barbarus causes $0.2 \%$ of grain yield losses during sowing and another $0.6-9.2 \%$ of losses during cereal growth (Baraibar et al., 2011). In addition, harvest losses can help Fusarium spores to survive, resulting not only in reduction of the cereal yield but also in contamination of grain with their mycotoxins (Pleadin et al., 2013).

On the other hand, harvest losses are also useful e.g. for birds as a food source (Robinson and Sutherland, 2002; Wilson et al., 1999).

Very good setup of the combine harvester is the most crucial prerequisite for reduction of the amount of harvest losses. Although combine harvester manufacturers provide recommended settings for every crop, these settings are based on average crop yields and average state of the undergrowth. Conditions during the harvest, especially the state of undergrowth, are usually not average, so with respect to the given conditions, the custom settings of the combine harvester provide an opportunity for reduction of harvest losses. Comparison of the harvest losses between manufacturer's default settings and custom settings based on operator's experience with the given crop and field is shown below. 


\section{Material and methods}

Experiments were carried out on the axial-flow combine harvester AXIAL CASE IH 9120.

\section{Method for determination of harvest losses}

The measurement of quantitative grain losses was made by comparison of the biological grain yield from the area of $1 \mathrm{~m}^{2}$ and grain losses during harvest, also from the area of $1 \mathrm{~m}^{2}$.

For determination of biological yield $\left(M_{b}\right)$, six squares with a side of $1 \mathrm{~m}$ (the area of $1 \mathrm{~m}^{2}$ ) were randomly chosen on each field. Subsequently, the plants from these areas were manually cut off; the grain was separated and weighed. Biological yield $\left(M_{b}\right)$ is the average yield of six plots per field.

To determine the amount of grain losses during the harvest, the area of $1 \mathrm{~m}^{2}$ was defined by the width of the harvester cutterbar $(10.4 \mathrm{~m})$. In order to obtain the space with the area of $1 \mathrm{~m}^{2}$ with one side based on the width of cutterbar, the second side of the rectangle was calculated as $0.0961 \mathrm{~m}$ (Fig. 1). All grain (damaged as well) from this area was collected and weighed. Harvest losses (Mg) are the average weight from at least three points for each field.

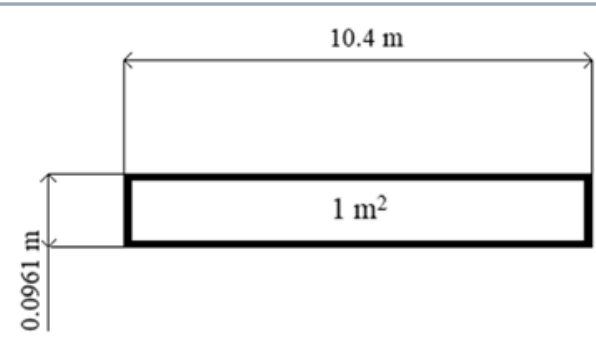

Fig. 1 Scheme of the rectangle behind the harvester (area of $1 \mathrm{~m}^{2}$ ) used for determination of harvest losses

The percentage of the quantity losses $\left(Z_{q}\right)$ is calculated as a ratio of harvest losses $\left(M_{g}\right)$ to the biological yield $\left(M_{b}\right)$ :

$$
Z_{q}=\frac{M_{g}}{M_{b}} \cdot 100,(\%)
$$

where:

$M_{g} \quad$ - average weight of grain collected behind the harvester on the area of $1 \mathrm{~m}^{2}, \mathrm{~kg}$

$M_{b} \quad$ - average weight of biological yield from the area of $1 \mathrm{~m}^{2}, \mathrm{~kg}$

\section{Method for comparison of different settings}

Two types of settings, recommended by the manufacturer and custom setting based on combine harvester operator's experience, were selected for comparison. Setup parameters for the combine harvester with axial flow were rotor speed, gap between rotor and separator, fan speed and opening of the upper and lower sieve. Measurements were carried out at five fields with different overall grain yields. Two adjoining courses on the field outside the traffic lines were selected. The combine harvester was using GPS navigation for moving on course. Determination of biological yields was performed in close proximity to the harvested area. Course for measurement was $100 \mathrm{~m}$ long, and the combine harvester used a constant speed of $4 \mathrm{~km} \cdot \mathrm{h}^{-1}$. This speed was selected for optimal sieve load. Points for measuring of harvest losses according the method for their determination were set at the $25^{\text {th }}, 50^{\text {th }}$ and $75^{\text {th }}$ meter (Fig. 2) (cf. Method for determination of harvest losses).

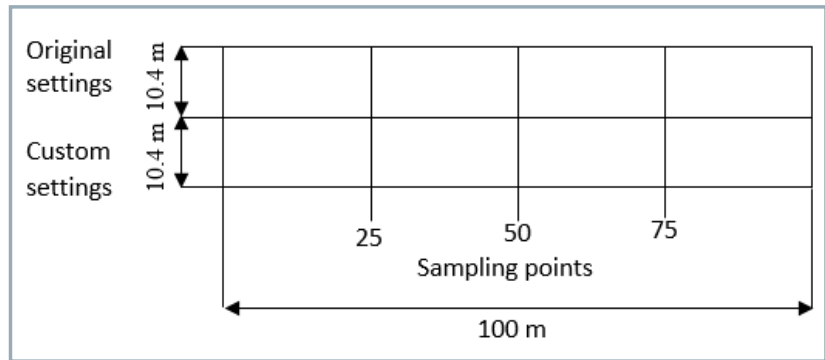

Fig. 2 Scheme of experiment setup on the field

\section{Results and discussion}

The setup overview of the combine harvester parameters for harvesting of spring barley and winter wheat is shown in Table 1. Custom settings differ from the settings recommended by manufacturer mainly in the gap between basket, rotor and bottom sieve openings (20\% and 29\%, respectively) for barley. Differences in custom settings for wheat are significantly greater than for barley. The gap between the basket and rotor was increased by $146 \%$ and the openings of the upper and lower sieves were significantly changed ( $42 \%$ and $77 \%$, respectively).

Testing was carried out at five fields with different average yields of barley and wheat. Resulting average losses are shown in Table 2. In all cases, lower losses were observed at

Table 1 Overview of the combine harvester settings for different crops

\begin{tabular}{|l||c|c|c|c|c|c|}
\hline \multicolumn{1}{|l|}{ Crop } & \multicolumn{3}{|c|}{ Spring barley } & \multicolumn{3}{c|}{ Winter wheat } \\
\hline Settings & recommended & custom & difference (\%) & recommended & custom & difference (\%) \\
\hline Rotor speed $\left(\mathbf{m i n}^{-1}\right)$ & 750 & 770 & +2.66 & 900 & 900 & 0.00 \\
\hline $\begin{array}{l}\text { Gap between rotor and } \\
\text { separator }(\mathbf{m m})\end{array}$ & 20 & 24 & +20.00 & 15 & 37 & +146.60 \\
\hline Cleaning fan speed $\left(\mathbf{m i n}^{-1}\right)$ & 900 & 900 & 0.00 & 980 & 1050 & +7.14 \\
\hline Openings of upper sieve $(\mathbf{m m})$ & 16 & 17 & +6.25 & 14 & 20 & +42.85 \\
\hline Openings of lower sieve $(\mathbf{m m})$ & 17 & 12 & -29.41 & 9 & 16 & +77.70 \\
\hline
\end{tabular}


Table 2 Average harvest losses of spring barley and winter wheat depending on combine harvester settings and overall grain yield

\begin{tabular}{|c|c|c|c|c|c|}
\hline \multicolumn{3}{|c|}{ Spring barley } & \multicolumn{3}{|c|}{ Winter wheat } \\
\hline $\begin{array}{c}\text { average yield } \\
\left(t \cdot h a^{-1}\right)\end{array}$ & $\begin{array}{l}\text { average losses at } \\
\text { recommended } \\
\text { settings }(\%)\end{array}$ & $\begin{array}{c}\text { average losses } \\
\text { at custom settings } \\
(\%)\end{array}$ & $\begin{array}{c}\text { average yield } \\
\left(t \cdot h a^{-1}\right)\end{array}$ & $\begin{array}{l}\text { average losses at } \\
\text { recommended } \\
\text { settings }(\%)\end{array}$ & $\begin{array}{c}\text { average losses } \\
\text { at custom settings } \\
(\%)\end{array}$ \\
\hline 4.284 & 0.52 & 0.41 & 4.759 & 0.58 & 0.49 \\
\hline 5.581 & 0.61 & 0.55 & 5.829 & 0.69 & 0.55 \\
\hline 6.188 & 0.71 & 0.59 & 6.531 & 0.75 & 0.63 \\
\hline 6.898 & 0.80 & 0.61 & 7.807 & 0.88 & 0.70 \\
\hline 7.543 & 0.95 & 0.68 & 8.039 & 0.97 & 0.75 \\
\hline
\end{tabular}

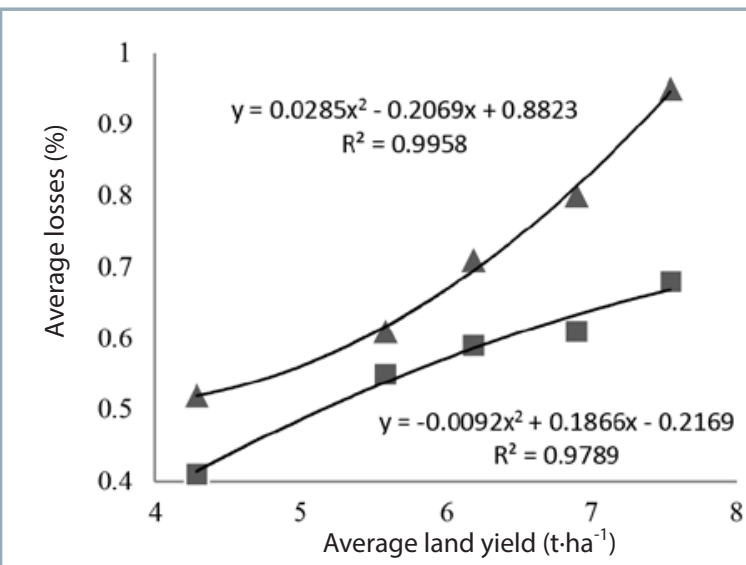

a) Spring barley

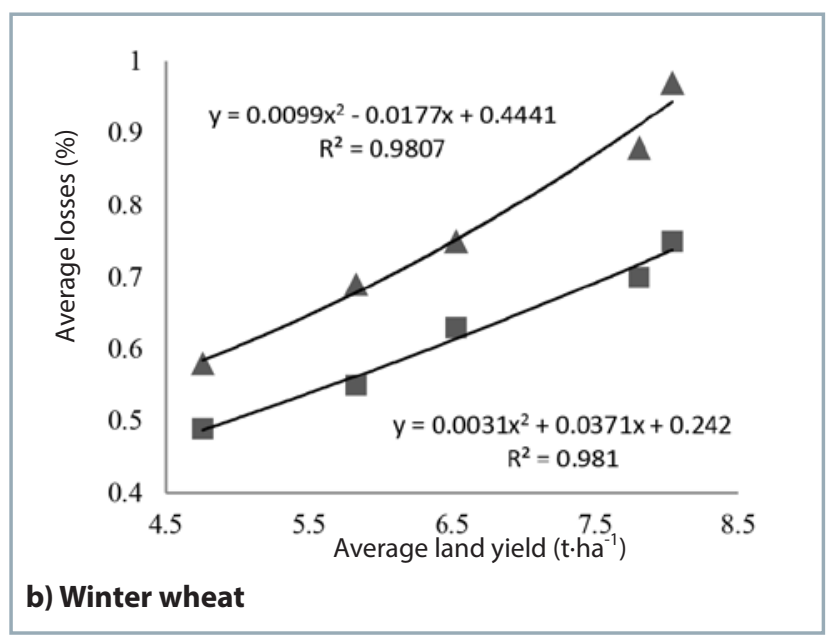

b) Winter wheat

Fig. 3 Grain losses of spring barley and winter wheat depending on the average grain yield and settings of the combine harvester $\boldsymbol{\Delta}$ - recommended settings of combine harvester parameters by the manufacturer, $\mathbf{\square}$ - custom settings of combine harvester parameters

custom settings for both barley and wheat. Considering the manufacturer's recommended settings, barley grain losses ranged from 0.52 to $0.95 \%$; losses at custom settings ranged from 0.41 to $0.68 \%$. For wheat, losses at recommended settings were from 0.58 to $0.97 \%$ and from 0.49 to $0.75 \%$ at custom settings. From the results, it is also clear that harvest losses relate to the average grain yield, with an increase in average yield, there is an increase in grain losses.

From the graphical representation of spring barley harvest losses (Fig. 3A), it is clear that the combine harvester settings resulted not only in lower losses but also in the course of their increasing with respect to the average grain yield. In both cases, losses on field with higher average yields were higher; however, in case of recommended settings, there was a sharp, almost exponential increase in yield losses. On the other hand, when custom settings were applied, the increase in losses with increasing average yield was much slower.

For wheat, it is clear from graphical representation (Fig. 3B) that the custom settings had an effect on overall lower losses, but their increase rate relative to the average yield is basically the same as the increase in losses at recommended settings.

Custom settings based on operator's experience have shown that in order to reduce losses, as many parameters as possible should be taken into account. For example, the gap between the rotor and the separator - if it is set to a small value, it will result in greater grain damage. Damaged grains are then taken away by the air flow from the fan due to their smaller weight, leading to an increment in harvest losses. Another important way how to reduce harvest losses is controlling the forward speed of harvester machine (Isaac et al., 2006). For better comparison of results, forward speed was constant $\left(4 \mathrm{~km} \cdot \mathrm{h}^{-1}\right)$ in all experiments.

For harvesting of smaller grains, similar in size to weeds, it is advisable to operate not only with the physical and mechanical properties of seeds but also with the biological properties. To solve these problems in the process of separating the sowing material of small seed mixtures, electric field can be applied as an additional working body (Kovalyshyn et al., 2015).

\section{Conclusion}

Quantitative loss values were always lower for custom settings than for the settings recommended by manufacturer. In harvesting barley, depending on the average grain yield from the given field, harvest loss ranged from $0.41 \%$ to $0.68 \%$ at custom settings, whereas at the recommended settings, losses ranged from $0.52 \%$ to $0.95 \%$. For wheat, results were similar. Harvest losses at the custom settings ranged from $0.49 \%$ to $0.75 \%$, while losses at recommended settings ranged from $0.58 \%$ to $0.97 \%$. Results show that 
good knowledge and operator's skills with harvesting process as a complex issue are necessary for reduction of harvest losses and, hence, increasing of economic yields, since the recommended settings are provided for average conditions that are not likely to occur.

\section{Acknowledgement}

The research has been supported by the project TP 6/2017: Defectoscopic quality assessment of technical and organic materials; financed by IGA AF MENDELU.

\section{References}

ALONSO-AMELOT, M. E. - AVILA-NÚÑEZ, J. L. 2011. Comparison of seven methods for stored cereal losses to insects for their application in rural conditions. In Journal of Stored Products Research, vol. 47, no. 2, pp. 82-87.

BARAIBAR, B. - LEDESMA, R. - ROYO-ESNAL, A. - WESTERMAN, P. R. 2011. Assessing yield losses caused by the harvester ant Messor barbarus (L.) in winter cereals. In Crop Protection, vol. 30, no. 9, pp. 1144-1148.

COEN, T. - VANRENTERGHEM, A. - SAEYS, W. - DE BAERDEMAEKER, J. 2008. Autopilot for a combine harvester. In Computers and Electronics in Agriculture, vol. 63, no. 1, pp. 57-64.

DO, T. D. T. - COZZOLINO, D. - MUHLHAUSLER, B. - BOX, A. - ABLE, A. J. 2015. Antioxidant capacity and vitamin $E$ in barley: Effect of genotype and storage. In Food Chemistry, vol. 187, pp. 65-74.

DIMITROV, P. - SIMEONOV, D. - STOYANOV, K. - KANGALOV, P. 2012 Effective aggregating of tractors for transportation. In Transport Problems, vol. 7, no. 3, pp. 25-28.

ELLIOT, J. - DERYNG, D. - MÜLLER, C. - FRIELER, K. - KONZMANN, M. - GERTEN, D. - GLOTTER, M. - FLÖRKE, M. - WADA, Y. - BEST, N. EISNER, S. - FEKETE, B. M. - FOLBERTH, CH. - FOSTER, I. - GOSLING, S. N. - HADDELAND, I. - KHABAROV, N. - LUDWIG, F. - MASAKI, Y. OLIN, S. - ROZENZWEIG, C. - RUANE, A. C. - SATOH, Y. - SCHMID, E. STACKE, T. - TANG, Q. - WISSER, D. 2014. Constraints and potentials of future irrigation water availability on agricultural production under climate change. In Proceedings of the National Academy of Sciences of the United States of America, PNAS, vol. 111, no. 9, pp. 3239-3244.

EUROSTAT. 2010. Employment in the agriculture sector down by $25 \%$ between 2000 and 2009. Eurostat News Release, 66/2010. Available at http://ec.europa.eu/eurostat/documents/2995521/5050706/507052010-AP-EN.PDF/5055cd01-7d45-4857-a4ab-758105496f58 GERRISH, J. B. - FEHR, B. W. - VAN EE, G. R. - WELCH, D. P. 1997. Self steering tractor guided by computer vision. In Application Engineering Agriculture, vol. 13, pp. 165-173.
IBANEZ, J. J. - GONZALEZ-URQUIJO, J. E. - GIBATA, J. 2014 Discriminating wild vs domestic cereal harvesting micropolish through laser confocal microscopy. In Journal of Archaeological Science, vol. 48, pp. 96-103.

ISAAC, N. E. - QUICK, G. R. - BIRRELL, S. J. - EDWARDS, W. M. COERS, B. A. 2006. Combine harvester econometric model with forward speed optimization. In Applied Engineering in Agriculture, vol. 22, pp. 25-31.

JONES, A. R - DALAL, R. C. 2017. Enrichment of natural 15N abundance during soil $\mathrm{N}$ losses under 20 years of continuous cereal cropping. In Science of The Total Environment, vol. 574, pp. 282-287.

KAHIL, M. T. - CONNOR, J. D. - ALBIAC, J. 2015. Efficient water management policies for irrigation adaptation to climate change in Southern Europe. In Ecological Economics, vol. 120, pp. 226-233. KANIEWSKI, D. - VAN CAMPO, E. - WEISS, H. 2012. Drought is a recurring challenge in the Middle East. In Proceedings of the National Academy of Sciences of the United States of America, PNAS, vol. 109, pp. 3862-3867.

KOVALYSHYN, S. - DADAK, V. - KONYK, S. 2015. Intensification of the process of preparing small seed crop mixtures. In Acta Technologica Agriculturae, vol. 18, no. 4, pp. 108-112.

KUTZBACH, H. D. 2000. Trends in power and machinery. In Journal of Agricultural Engineering Research, vol. 76, no. 3, pp. 237-247.

LAHOUAR, L. - POCHART, P. - BEN SALEM, H. - EL FELAH, M. MOKNI, M. - MAHNE, F. - MANGIN, I. - SUAU, A. - PEREIRA, E. HAMMAMI, M. - ACHOUR, L. 2012. Effect of dietary fibre of barley variety 'Rihane' on azoxymethane-induced aberrant crypt foci development and on colomic microbiota diversity in rats. In The British Journal of Nutrition, vol. 108, no. 11, pp. 2034-2042.

PLEADIN, J. - VAHCIC, N. - PERSI, N. - SEVELJ, D. - MARKOV K. - FRECE, J. 2013. Fusarium mycotoxins' occurrence in cereals harvested from Croatian fields. In Food Control, vol. 32, no. 1, pp. 49-54.

ROBINSON, R. A. - SUTHERLAND, W. J. 2002. Post-war changes in arable farming and biodiversity in Great Britain. In Journal of Applied Ecology, vol. 39, pp. 157-176.

WAHBI, A. - SINCLAIR, T. R. 2005. Simulation analysis of relative yield advantage of barley and wheat in an eastern Mediterranean climate. In Field Crop Research, vol. 91, no. 2-3, pp. 287-296.

WILSON, J. D. - MORRIS, A. J. - ARROYO, B. E. - CLARK, S. C. BRADBURY, R. B. 1999. A review of the abundance and diversity of invertebrate and plant foods of granivorous birds in northern Europe in relation to agricultural change. In Agriculture, Ecosystems \& Environment, vol. 75, no. 1-2, pp. 13-30. 